\title{
Improving useful species: a public policy of the Directoire regime and Napoleonic Empire in Europe (1795-1815)
}

\author{
LAURENT BRASSART
}

KEYWORDS: Napoleonic wars, circulation of species, biological policy, naturalists.

JEL CODES: N43, P48, Q28, Q38.

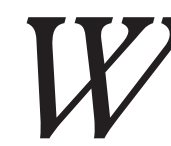

Ten the French Revolutionary and Napoleonic Armies conquered most of Europe, they found unknown or hardly known plant and animal species.

French naturalists, particularly the so-called agronomists led by botanists and zoologists, supported by the financial and political backing of the State, shaped an ambitious "Nature Policy". They imported new species of plants and animals from the occupied territories to introduce them into France. The biological regeneration of French herds and agriculture was the main goal of this public policy. A unidirectional circulation from throughout the European continent towards France occurred from 1799 to 1815. But the continental blockade in 1806 cut off the supply of certain products and raw materials such as sugar, indigo and cotton. On a continental scale, in the most adapted parts of its Empire the Napoleonic State implemented an impressive policy of introducing and acclimatizing exotic plant species from many regions of the world. Many questions arise from this unprecedented circulation of plant and animal species within "French Europe": How was it organised? On which circuits and networks did it rely? What was the role of the French state in that biological challenge? Finally, why were the results of that biological policy so disappointing? 


\title{
Melhorar espécies úteis para a Europa: uma política pública do regime do Diretório e do Império Napoleónico (1795-1815)
}

\section{PALAVRAS-CHAVE: guerras napoleónicas, circulação de espécies, políticas biológicas, naturalistas.}

\section{CÓDIGOS JEL: N43, P48, Q28, Q38.}

\begin{abstract}
$Q$ uando a Revolução francesa e os exércitos de Napoleão conquistaram a Europa, confrontaram-se com espécies vegetais e animais desconhecidos ou mal conhecidos. Os naturalistas franceses, especialmente os chamados agrónomos, uderados por botânicos e zootécnicos e apoiados pelo impulso financeiro e politico do Estado delinearam uma "Política da natureza» ambiciosa. Novas espécies de plantas e animais foram importadas a partir dos territórios ocupados e conduzidas e introduzidas em França. A regeneração biológica da criação de gado e da agricultura francesa foi o objetivo principal desta política. Uma circulação unidireccional, de todo o continente europeu para a França, ocorre entre 1799 a 1815. Mas o bloqueio continental, em 1806, vai cortar o fornecimento de alguns productos e matérias-primas como o açúcar, o indigo ouo algodão. A uma escala continental, nos espaços mais adaptados do seu império, o Estado napoleónico implementou uma política impressionante de naturalização e aclimatização de espécies vegetais exóticas vindas de todo o mundo. Acerca desta circulação sem precedentes de espécies vegetais e animais dentro de «Europa francesa”, podem ser colocadas muitas questões: ¿Como foi organizada? Em que os circuitos e redes se apoiou? Qual foi o específico papel do Estado francês neste desafio biológico? ¿Finalmente, porque foram os resultados dessa política biológica tão decepcionantes?
\end{abstract}

Received: 2016-07-12 - Revised: 2017-04-28 • Accepted: 2017-05-16

Laurent Brassart [orcid.org/0000-0002-4305-3124] is Assistant Professor of Modern History in Université de Lille, Sciences Humaines et Sociales. Address: BP 60149, Université de Lille, Sciences Humaines et Sociales, F-59653Villeneuve d'Ascq (France).Email: laurent.brassart@univ-lille3.fr 


\section{INTRODUCTION}

During the French Revolution and the Napoleonic Empire (1789-1815), the circulation of animal and vegetal species quickly increased throughout the European continent. Three events, intrinsically connected with the geopolitical evolution, created new conditions for the circulation of species.

In the second half of the $18^{\text {th }}$ century, French naturalists (interested in zoological and veterinary matters) thought that the national herds of useful animals (ovine, bovine and equine herds) were totally degenerated ${ }^{1}$. But customs barriers prevented the European mercantilist states from introducing new species in large quantities. With the military conquest of most of Europe by the French revolutionary and Napoleonic armies, the customs barriers were removed and it became much easier to set up a wide-ranging policy of regeneration of the national herds at low cost (Brassart, 2014a). From 1794 to 1815, a great wave of animal species (precious Merino sheep from Castile, stallions from the Ottoman Empire and Prussia, buffalos from Italy, cows from the Netherlands, Switzerland and Italy) began to flow from many parts of Europe to a common destination: France. Thus, a veritable policy of animal and botanical predation in the occupied territories was set up and encouraged by the agronomists of the Directoire Regime (1795-1799) and the Napoleonic Empire (1800-1815) (Lacour, 2014).

But, two other events deeply changed the rules of the scientific game during the Napoleonic Empire. The continental blockade, which began in 1802, and the control of the seas by the Royal Navy, after its naval victory at Gibraltar over the Franco-Spanish fleets in 1805, put an end to trade between the continent and the colonies. The impact of these geopolitical events was more important for botany than for zoology. Of course, the import of English stallions was prohibited all over Europe by the decree of Thermidor $13^{\text {th }}$, Year IX (August 1 $\left.{ }^{\text {st }}, 1801\right)^{2}$ but, more importantly, the great French botanical expeditions overseas stopped and the collection of exogenous plants and seeds became impossible (Bourguet, 1997). The main consequences were on the textile and sugar industries: the manufacturers no longer received cotton and dyeing plants and the consumers had to go without sugar. That's why the Napoleonic State requested its scientists to find a solution to the loss of colonial commodities. If the production of substitutes such as sugar from beetroots is well known, the attempts at acclimatization of the cotton and dyeing plants in the Mediterranean areas of the Empire are quite unknown.

1. About the importance of the new concepts of generation/degeneration in the $18^{\text {th }}$ century, see SPARY (2000) and Doron (2016).

2. Annales de l'agriculture françoise, 1801, t. 8, an XI, pp. 376-97. 
With a situation of permanent war for 20 years, it became more and more difficult to produce enough food in the Empire. The Napoleonic State had to feed the largest army ever (around 680,000 soldiers in 1812, before the Russian campaign) and, from 1807 onwards, many civilian people could no longer stand such hardships and protested against the Napoleonic order. For the first time since 1800, finding and supplying cheap commodities became a priority. The State encouraged the production of leguminous plants, potatoes, swedes and other roots (Spary, 2012, 2014). What they aimed at, though, was to acclimatize those species, and have them consumed by as many people as possible.

How did the Napoleonic State take up those scientific challenges (the regeneration of animal species which the country needed, the replacement of colonial products with homemade products and a solution to food shortage) largely due to the geopolitical situation?

\section{COLLECTION, ACCLIMATIZATION AND HYBRIDIZATION IN NATIONAL ESTABLISHMENTS}

The imperial administration set up, in the territories which had been conquered, an ambitious agricultural policy, mainly designed by an elite of agronomists (Brassart, 2014b).

André Thouin, Antoine Augustin Parmentier, Jean-Baptiste Huzard, Henri-Alexandre Tessier, Jacques-Philippe Martin Cels, Philippe-Victoire de Vilmorin, among others, gave direct advice to the State as members of the Agricultural Section of the General Committee of Agriculture, Art and Trade, an advisory organ of the Ministry of the Interior (Moullier, 2004). This Agricultural Section regarded itself as an interlink between the political and scientific spheres. Indeed, being members of the National Institute, teaching at the Museum of National History or at the Veterinary School of Alfort, these agronomists, whose advice guided the agricultural policy of the State, were so prestigious that they could easily mobilise, what would be called an international agronomic think tank nowadays (Margairaz, 2005).

Upon their advice, the Napoleonic State reopened the great experimental institutions set up by the Ancien Régime and closed during the Revolution. Thus, the veterinary schools of Lyon (founded in 1761) and Alfort (1766) were completely remodelled by the Imperial Decree of January $15^{\text {th }}, 1813$. Now, only the school of Alfort was considered first class; the future veterinary doctors had to study for five years whereas the veterinary marshals had only to study for three years. The latter were formed in the four second-class schools. Lyon had been downgraded from first to second class and three new second-class schools were created in the departments which had been annexed:Turin, Aachen and Zut- 
phen (in the Netherlands). The graduates from these five veterinary schools were assigned to the departments to carry out the prefects' mission: improving the breeds of animals and fighting epizootic diseases. An elite of veterinary doctors and zoo-technicians who had graduated at Alfort were required to teach veterinary art and design the policy of regeneration of useful animals (Mellah, 2015; Berdah, 2012).

Besides the veterinary schools, national breeding institutions were opened or reopened. By the decree of July $4^{\text {th }}, 1806$, the Emperor, upon the advice of the Bureau of Agriculture, reestablished national stud farms: a network of 6 stud farms, 30 depots and two schools covered the territories under the control of the Empire ${ }^{3}$. These stud farms and depots had the best stallions from all the breeds which were declared qualified to regenerate the local ones. Of course, those stallions no longer came from Britain, as they had done since the mid- $18^{\text {th }}$ century because the decree of Thermidor $13^{\text {th }}$, Year IX (August $1^{\text {st }}, 1801$ ) had banned their import ${ }^{4}$. But new breeds were introduced on a large scale, such as the Arabian stallions, brought back from the Egyptian expedition of 1798 and popular with the light cavalry and the Emperor for their sprightliness. The breeds from the Ardennes and Brittany, whose stamina and hardiness made wonders in the transportation and artillery regiments which used them as saddle or semi-draught horses were put into general use, just like the German breeds which, after the battle of Iena in 1805, successfully replaced the French draught breeds used by the heavy cavalry until then.

In the national stud farm of Pompadour, from 1806 to 1815, 20\% of the stallions were Arabian. They were used, in particular, to regenerate the local breed (Limousin horses) which had been considered for a whole century as the best for riding. By crossing Arabian stallions and Limousin mares the stud farm was able to provide taller and more resistant horses which were particularly valued by the army and race horse breeders (Blomac, 2006).

It was thus within the stud farms and depots that an unprecedented cross-breeding of horses was carried out. It is also there that the hybridization of breeds was experimented, one of the most famous being an attempt at improving saddle and semi-draught Ardennais horses by cross-breeding them with Arabian stallions.

This was also true for sheep farming. The national sheep farm of Rambouillet, which had been founded in 1786 near the Castle ofVersailles to receive the first herd of $366 \mathrm{Me}-$

3. Annales de l'agriculture françoise, 1806, t. 27, p. 289. About the National studs farms before the French Revolution, see MULLIEZ (1983).

4. Ibid., 1801, t. 8, an IX, pp. 376-79. 
rinos purchased by King Louis XVI of France from his cousin Charles III of Spain, was reopened (Bourde, 1967: 872, 877). The Revolution and the Napoleonic Empire carried on this experiment: ten other national sheep farms were created between 1800 and 1808 so as to keep and breed Merinos brought back from Spain after the Basel Peace Treaty (July $22^{\text {nd }}, 1795$ ) between the French Republic and Spain which had been defeated ${ }^{5}$. All of them had to preserve the purity of Merino sheep from the Leon region, through the selection and reproduction of the animals. Spanish shepherds were even recruited before a sheep farming school in Alfort and Rambouillet opened in 1800 until 1805 (Mellah, 2013). Once they had enough herds of acclimatized Merinos, a few sheep were sold at auction to private farmers. The latter then started improving their own stock by crossbreeding them with Merinos. Crossbred herds thus appeared; their wool was not as good as that of pure Merinos but it was much better quality and produced in larger quantities than that of traditional breeds. Besides improving local herds, the aim was mainly to produce the fine and cheap wool demanded by sheet manufacturers. Reducing the cost of production in national manufactures, dispensing with costly imports of Merino wool from Spain and producing high quality sheets -needed in particular for the Grande Arméewas what prompted the breeding of sheep with methods which were more and more scientific and better and better suited to the needs of industry.

Other useful animals came from all parts of the continent. For the Rambouillet state farm only, the distribution of the 595 animals from different breeds on October $23^{\text {rd }} 1801$ is eloquent in this respect: the sheep pens housed 497 Merinos from Spain, the stables 36 horses from Spain, Italy and Egypt, in addition to a Tuscan mule, and the cattle sheds 46 cattle and 14 buffalos from Italy ${ }^{6}$. These buffalos had been bought from the Pope in 1797 to be introduced in France: they were supposed to regenerate the French cows by cross-breeding ${ }^{7}$.

Finally, as far as plants are concerned, another network uniting experimentation and transfer of scientific discoveries was established in all the departments of the Empire. The National Museum of Natural History and the Jardin des Plantes were at the heart of the system. The decree of Floreal $6^{\text {th }}$,Year II (April 25 ${ }^{\text {th }}, 1794$ ) which created it stipulated that the Museum is, so to speak, a common reservoir which will provide other gardens with plants

5. 8 sheep farms were located in France and 2 in Germany: Rambouillet and Malmaison (Seine et Oise), Pompadour (Corrèze), Arles (Bouches-du-Rhône), Saint-Geniés-Champanelle (Puy-deDôme), Cére (Landes), Saint-Georges-de-Romains near Villefranche (Rhône) and Clermont near Nantes (Loire-Inférieure), in France; Aachen (Roer) et Ober-Emmel near Trier (Sarre), in Germany (Tessier, 1839).

6. Annales de l'agriculture françoise, 1802, t. 10, an X, pp. 110-12.

7. Ibid., 1814, t. 58, pp. 193-251. 
and will receive others from them in exchange; those gardens will spread light around themselves, as an example of an enlightened way of growing plants (Guillaume, 1891: 510).

There, André Thouin gave lessons to botanists and experimented on the acclimatization of exotic plants (Lacour, 2014: 341-46). He promoted the practical application of discoveries as well as research: he founded and ran schools which were more intended for gardeners than for scientists. At the School of Fruit Trees and Common Plants, for instance, acquiring scientific knowledge about plants was considered less important than knowing how to use them in a garden. For example, at the School of Useful Plants, a distinction was made between plants grown to feed humans, those used to feed cattle and domestic animals and, finally, those used in industry. In the same way, the object of the School of Fruit Trees, according to André Thouin, was:

to help botanists and farmers study this beautiful part of the vegetable world which has been neglected until now [...], to find among the different names used for plants those that are similar in French and other languages, so that a uniform nomenclature can be used in all the French territories; [...] to naturalize, and multiply, first, and then spread in all the department, the fruit trees which can be used to feed men or produce drinks which are both healthy and pleasant (Thouin, 1803).

Still, Thouin did not only insist on the utilitarian aspect of education at the Museum; he also fostered scientific research. His main object was to acclimatize plants which were considered useful, whatever their use: plants for the industry or plants grown to feed humans or animals. Even more important, the Jardin des Plantes, next to the Museum of National History, was established as the nerve center of a vast network of national nurseries.

The State had a strong hold over those experimental centers. An administration was set up for each of them, with at their head an elite of agronomists who were experts in the field: Huzard, a veterinary surgeon, was appointed general inspector of imperial stud farms, Tessier, "the father of French Merinos", who was at the head of Rambouillet, became inspector of imperial sheep farms and Bosc, a botanist, was appointed inspector of the Versailles nurseries in 1804 and of those of the Ministry of the Interior (the Luxembourg and Roule nurseries in Paris) after Cels' death in 1806.

They all wrote books and articles giving practical advice to farmers and drafted the official instructions from the Ministry of the Interior which had to be scrupulously implemented by the national establishments in order to improve species. The owners and farmers were also strongly advised, in the interest of their farms, to conform to those official norms (Huzard, 1801; Tessier, 1810). 
Animal and vegetal experimentation was thus carried out within the various national institutions with a double aim: first, to collect, introduce and acclimatize new species; second, to try to hybridize or crossbreed species or breeds. A few questions remain, though: how could scientific and experimental research be applied locally? How could agronomical knowledge be transferred from the scientific level to the farmers' level?

\section{FROM THE NATIONAL EXPERIMENTAL ESTABLISHMENTS TO THE FARMERS}

Several points of contact between the scientific and agricultural spheres were envisaged by those who designed the agricultural policy of the Empire: the national institutions themselves but also the network of agricultural societies and the agronomic press.

Within the various public institutions, permanent contact was established between the scientists who carried out experiments and private landowners and farmers. Right from the start, it was decided that the transformations in agriculture had to be financed and implemented both by the State and private actors ${ }^{8}$. The sharing out of roles was simple: the State was to collect new species, preserve the purity of the breeds and seeds and try and acclimatize and hybridize them; private actors were to acquire pure or successfully hybridized specimens from the institutions so that they could "regenerate" their stock. Private farmers, for instance, could come to the national stud farms with their mares and pay to have them covered by stallions selected for the purity of the breed and guaranteed to be perfectly standard. Farmers could also buy new plants and trees from the departmental public nurseries. Let us examine, for example, the imperial sheep farms. Every year since the decree of Germinal $10^{\text {th }}$, Year X, they had to organise a sale at auction of wool from their own pure Merinos or from half-breeds (half Merino, half local breed) and Merino and half-breed sheep born on the farm. This system was set up for several reasons. The first one was financial: the institutions were thus guaranteed revenues of their own; the second one was managerial: it enabled them to regulate their stock, in particular after the lambing period; the last one was agricultural: they could thus introduce Merino rams into private herds. At least, with the 11 imperial sheep farms, the introduction of Merinos was particularly successful: in 1811, there were 200,000 pure Merinos, and 2 million cross-breed sheep in France! (Moriceau, 2005: 160).

8. This idea was clearly expressed by Augustin-François Silvestre, the secretary of the Agricultural Society of the Seine Department and director of the Bureau of Agriculture of the Ministry of Interior in his book (SILVESTRE, 1800). 
To help each private owner merinise his indigenous flock more easily, by using the few rams he had bought from a national sheep farm, Tessier, the general inspector for these national sheep farms wrote his Instruction about woolly animals and particularly about the Merino breed including advice on how to make up good flocks and how to multiply them, keep them healthy and cure them when they are ill. Of course this book, published in 1810, was financed by the Ministry of the Interior.

In the same way, the decree of Fructidor $13^{\text {th }}$, Year XIII (August $30^{\text {th }}, 1805$ ), by reestablishing horse races, was a form of official encouragement to the improvement of horse breeds by private owners. The possibility to increase profits by selling improved race horses must have encouraged the breeders to use Arabian stallions from the national stud farms ${ }^{9}$. The decree by the Ministry of the Interior of October $5^{\text {th }}, 1810$, had the same effect; it multiplied restrictions aiming at excluding as many horses as possible from the races: a minimum time-length to run a distance was established by the panel of a racecourse, for instance, or a certificate from the owner establishing the origin of the horse was required $^{10}$. In 1811, Silvestre, the head of the Bureau of Agriculture of the Ministry of the Interior and secretary of the Agricultural Society of the Seine Department, made no secret of the object of those measures:

Secondary races have been established in some departments and these institutions, which entertain the masses, also spread some exact knowledge and bring to light the most noticeable qualities of some horses and those which will be developed by the farmers because it is in their interest to improve their horses through alliances, crossbreeding and education ${ }^{11}$.

In many departments, competitions with high prizes were organised during agricultural fairs to promote the best colts, mares and stallions. Thus, breaking with the practices of the Ancien Régime, the program designed by Jean-Baptiste Huzard under the Consulate and the Empire aimed at uniting fully the notables to the scientists (veterinary surgeons) and local administrators (prefects and members of the general councils) in a common effort to improve horses which were largely motivated by financial gains (Roche, 2008b).

9. About the impact of horse races on the birth of new horses, see BlomaC (1991).

10. Annales de l'agriculture françoise, 1810, t. 44, pp. 198-202.

11. Mémoires d'agriculture et d'économie rurale et domestique publiées par la société d'agriculture du département de la Seine, 1811 , t. 14, p. 8. 
In the end, this policy brought about a spectacular increase in the equine population of France. Due to the closing of the stud farms during the Revolution and requisitioning which had been constant from 1792 to 1794, the number of horses, donkeys and mules had dropped considerably although it is difficult to say precisely how much because those who tried to assess it did not agree on the exact proportion (it must have been from $20 \%$ to one third). And yet, according to Daniel Roche, less than 20 years later, around 1812, a census of the horse population in the 89 departments of Imperial France numbered 2,506, 494 animals, which represents an increase of over one million, or 150\% (55,000 horses a year) (Roche, 2008a: 82-121). The recovery of the horse population, both in quantitative and quality terms is undoubtedly the result of the imperial policy (Roche, 2008b).

In each important park of the Paris region experimental nurseries, which were directly run by the Ministry of the Interior, were established. The main national nurseries in $\mathrm{Pa}-$ ris were the one at the Roule and, more important, the one at the Jardin du Luxembourg. The latter, created by Chaptal, the Interior Minister, gathered, over 9.5 ha in the heart of Paris, specimens of all the species of vineyards known in the Empire and allegedly possessed up to 200,000 species of fruit (Calvel, 1805: 213-16). Next to them, the Imperial Residence of Malmaison, held a botanical garden which was reserved for the most curious species, indigenous as well as exotic; Empress Joséphine distributed seeds and cuttings to the departmental nurseries. Finally, the Imperial Household ran another nursery, that of Versailles Trianon which was under the responsibility of $\mathrm{M}$. Bosc, one of the most eminent botanists of the Empire -together with Jacques Martin Cels and André Thouin- even if it is more difficult to know whether it distributed seeds and cuttings or not (Calvel, 1805: 212-13).

Just like at the Jardin des Plantes of the Museum of Natural History, experiments at acclimatizing and hybridizing European and North American trees were carried out. Thus, Chaptal, the Minister of the Interior, made them collect and gather, at the nursery of the Luxembourg, from 1804 to 1807, all the European grape varieties, so that Bosc could classify, study and hybridize them if necessary (Bosc, 1807).

What this new inspector of the national nurseries aimed at was acclimatizing new grape varieties in the regions where bad wine was produced, in the Paris region, in particular. At the Versailles nursery, another type of acclimatizing was tried out, that of the sweet potato from tropical America which was used to feed black slaves. Much was made about successfully acclimatizing it under a temperate climate: the sweet potato is easy to grow, with no manure, under a little mound of earth and must be planted in spring to be harvested in summer. Le Lieur's conclusion was: I am happy to say that this is a conquest of 
productions from the NewWorld by French agriculture. This root is so good, it requires so little to be grown, that we can be sure it will be an important acquisition, which will be enjoyed by future generations, who will say that this is another beneficial effect of the reign of $\mathrm{Na}$ poleon. It was hoped that this root, together with the ordinary potato, would enable the regime to feed at low cost the "lower classes" of society. In order to promote this, the empress distributed specimens from herVersailles Trianon garden to imperial dignitaries, encouraging them to plant them in their own gardens. It was hoped by this stratagem to arouse interest, if not envy among poor peasants (Bosc, 1807: 319-52). From the years 1807-1808 onwards, at a time when the economic and military situation of the Empire was beginning to deteriorate, there was a renewed interest from the government in roots such as the sweet potato, the Swedish turnip (rutabaga) and the Jerusalem artichoke. The latter's interest, in particular, was well understood because it did not freeze when left in the ground and could be used to feed animals ${ }^{12}$.

Just like with horses, the object was to collect all known species so that they could be used in all the departments of the Empire. The Directoire regime, which had created the central schools in each department on February $25^{\text {th }}, 1795$, to form the new ruling elite, endowed them with botanical gardens for the study of plants and scientific experimentation on them. The Museum of National History of Paris had to send them specimens of the plants they had successfully acclimatized or hybridized. From 1798 to 1802 (the year when those schools were closed to be replaced by a new system of secondary schools), the Museum, under the direction of André Thouin, sent them over 55,000 packets of seeds and 6,500 living plants (Lacour, 2014: 467).

A directive from Chaptal, the Minister of the Interior, invited each prefect to establish a nursery in his department. The Jardin des Plantes of the National Museum of National History and the national nurseries of Paris were to send to these departmental nurseries specimens of plants and seeds from new species which were worth being acclimatized. These departmental nurseries were often run by the societies of agriculture of the departments. Thus, the Society of Agriculture of Turin prided itself on having introduced in its experimental garden a few useful plants, such as the peanut, the yellow turnip, the rhubarb or the Polish wheat. After having successfully naturalized them, the Society of Agriculture of Turin distributed those species to a few big landowners who, in particular for the peanut, grew them on a large scale. [...] This oil-producing plant is now so extensively grown that it can be regarded as naturalized in Piémont ${ }^{13}$.

12. Annales de l'agriculture françoise, 1806, t. 28, pp. 282-86; 1809, t. 36, pp. 251-60.

13. Almanach du département du Pô pour l'an 1809, 1809, Turin, Michel Ange Morano, p. 201. 
The latter example illustrates the connection between research and its transfer to private individuals since when it was confirmed that a new species could be acclimatized there, they could sell new seeds or give them for free to those individuals.

Agricultural progress, and in particular the introduction of new species, was largely promoted by the powerful network of agricultural societies that the Directoire had reestablished in 1796 and that the Empire had imposed systematically in each department. The Revolution had given the final blow to the moribund agricultural societies of the Ancien Régime with the law of August $8^{\text {th }} 1793$, but the Empire could boast about having 85 of them in $1805^{14}$. The initiative was political, then, and was a top-down policy but it was also supported by the notables in the departments. More important, these agricultural societies were patronized by two compelling authorities: at the local level, first, the prefect gave important subsidies which they needed to be able to operate but also at the national level with the Agricultural Society of the Seine Department, the meeting place of a real national agronomic elites, set up by the Ministry of the Interior as the nerve center of all the agricultural societies. A techno-power at the juncture of three spheres (the administration, the scientific world and agriculture) had thus been created by the Empire.

It was within this parent society that the main projects of acclimatization of useful plants and animals were discussed. As early as 1806 , for instance, they debated about the opportunity of replacing coffee by chicory from northern Germany. They did not immediately come to any final decision because Neufchâteau and Tessier, the two leading experts, were irremediably opposed about this topic ${ }^{15}$ but a campaign of opinion was launched: the Danish correspondent of the Bruun-Neegard company, with the support of Tessier, published a paper in which he promoted the introduction of chicory in the departments of the Empire (Bruun-Neergard, 1808). It was only when the botanist De Candolle reported about his agronomic travels in Dauphiné -where chicory was present and used in small quantities- and, more importantly, in Belgium, that the agricultural Society of Paris finally recognized how beneficial growing and consuming the drink produced with it was ${ }^{16}$. As early as 1811 , it was strongly recommended to grow it on a large scale.

From Paris, the transfer of agricultural innovation was doubly top-down: decisions taken by the Minister of the Interior were transmitted to the prefects in each department who had them implemented by the local agricultural societies; the Agricultural Society

14. Archives nationales, F10 202.

15. Annales de l'agriculture françoise, 1808, t. 34, pp. 204-20.

16. Mémoires d'agriculture et d'économie rurale et domestique publiées par la société d'agriculture du département de la Seine, 1811, t. 14, pp. 213-34. 
of the Seine Department sent the yearly Mémoires it published to all the departmental societies and encouraged them to have them transfer instances of innovation locally, via, for example yearly competitions with high prizes.

This example was imitated by the agricultural societies in the departments. Out of the 6 prizes it offered in 1811, the Agricultural Society of Cleves in the Roer department (actually in Germany), three were devoted to efforts at acclimatization:

one prize for the most beautiful stallion of a foreign breed used for reproduction in the district of Cleves, and bought in 1810 in a foreign country; one prize for the best bull of a foreign breed used for reproduction [...] and bought in 1810 in a foreign country; one prize for the biggest and the most beautiful nursery, which was planted in 1801 in the district of Cleves ${ }^{17}$.

The imperial government's willingness to transform nature and French agriculture is best illustrated by the Cotton Plan which was launched in 1806. The annihilation of the Franco-Spanish fleet at Trafalgar in October 1805 and the setting-up of the continental blockade in 1806 cut off the supply of that raw material and so nipped in the bud the new textile industry which was then burgeoning. An idea was then born in the Ministry of the Interior: introducing cotton in the Mediterranean departments of the Empire, from Rome to Perpignan. The French ambassadors in Spain and Portugal and the prefects in the Italian departments were ordered to send reports about the experiments at acclimatizing cotton which had already been carried out in these south-European countries. These reports boded well for the chances of success of this culture. A circular from the Ministry of the Interior was promulgated on March $7^{\text {th }} 1808$ and urged all the captains of French vessels to get hold of cotton seeds and send them to France, fraudulently if necessary ${ }^{18}$. This attempt at acclimatizing cotton now looks like an unrealistic dream but, at the time, an allegedly successful experimentation at Malta seemed encouraging. Maltese people were even recruited to try and acclimatize it in the Empire and Tessier, in 1801, wrote an official report about how the plant was successfully grown in this Mediterranean island (Tessier, an IX).

In addition, the Society of Agriculture of Paris organised a big imperial competition in 1807 whose object was the introduction of cotton growing in France ${ }^{19}$ ! A few projects

17. Annales de l'agriculture françoise, 1810, t. 45, p. 247.

18. Archives nationales. F10 416, dossier 1.

19. Mémoires d'agriculture et d'économie rurale et domestique publiées par la société d'agriculture du département de la Seine, 1807, t. 10, pp. 55-61. The amount of the prizes (2,000 francs for the winner 
were received and awarded prizes. But the supply of cotton seeds in 1807 and 1808 was slow and irregular. All the seeds were sent to the Bureau of Agriculture which handed them over to the Jardin des Plantes of the Museum of Natural History and to the national nurseries so that they could try and acclimatize them and report on the scientific observations which had to be taken into account for the future success of the operation. One year later, the seeds they had been able to harvest in the national nurseries were shared out among the 21 southern departments the board of agriculture of the Ministry of Interior had selected for the acclimatization of cotton.

Together with the seeds, the prefects received instructions based on the results which had led to prizes being awarded by the Society of Agriculture of the Seine and whose publication was financed by the Bureau of Agriculture of the Ministry of the Interior. The main official publications were Instruction sur le cotonnier et sa culture (Instruction about the cotton plant and how to grow it), by Charles Philibert de Lasteyrie and Instruction sur la manière de cultiver le coton en France (Instruction about how to grow cotton in France), by Henri-Alexandre Tessier, both members of the Agricultural Society of the Seine Department ${ }^{20}$.

These instructions were then sent down to the under-prefects and societies of agriculture who gave them to those of their members who were willing to try their hand at this new kind of crop. They all pledged they would try and acclimatize cotton and they had a very good reason for that: the Minister of Agriculture had promised, in a circular of March $20^{\text {th }} 1807$, that any farmer who had harvested cotton, cleaned it and made it ready for spinning would be awarded one franc per kilo ${ }^{21}$. The authorities at all levels of the hierarchy spared no effort to make it known. Such was the case of the prefect of the Gard Department who had the Ministry's circular stuck on the walls of every village ${ }^{22}$ !

After a first campaign of trials in 1807, which was unsuccessful, the government did not give in. Tessier, the eminent naturalist, the editor of the Annales de l'agriculture françoise, and a member of the Institut National and the Agricultural Council of the Ministry of the Interior, was asked to reprint his instruction about how to grow cotton in France

and 1,000 francs for those who had not come first) show how important this was for the main agricultural society of the Empire.

20. Archives nationales, F10 416, dossier 1. The instruction of Charles Philibert de Lasteyrie was published in 1808 with this new title: Du Cotonnier et de sa culture, de la possibilité et des moyennes d'acclimater cet arbuste en France.

21. Archives nationales, F10 416, dossier 3.

22. Ibid. 
with a supplement devoted to the results of the first attempts at growing it in 1807 (Tessier, 1808). The lessons which could be drawn from the winter failures were to guarantee future success.

It is clear then that the Napoleonic State took the necessary steps to achieve the great biological change it wished to bring about in agriculture.

\section{THE TRANSFORMATION OF PLANTS AND ANIMALS DURING THE EMPIRE: NEITHER AUSTERLITZ NOR WATERLOO!}

Why were the results disappointing? Many reasons may explain why. Let us account for a few of them.

In such a centralized agricultural state system, the dysfunctions of the bureaucracy are one of the reasons of the failure. The failure of the Cotton Plan of 1806-1808 is the best case in point. Many prefects accounted for the disappointing results of the attempts at growing cotton in their departments in 1807 and 1808: they explained that they had received too few seeds and, even worse, that the Bureau of Agriculture had sent them far too late: some of them had received the seeds in June and they should have been sown in March! In 1807, out of the 21 departments which had tried to grow cotton, only 13 had managed to harvest it and in very small quantities ${ }^{23}$. The results in the next years were as unsuccessful. The most obvious admission of failure occurred in 1814, when the Agricultural Society of the Seine Department (Paris), which was at the head of the imperial agricultural societies' network, cancelled the introduction of cotton in the Empire from the program of its competitions ${ }^{24}$ !

Ill-resolved scientific debates may also explain the disappointing results. Considering the number of circulars and other agronomical documents published by the Ministry of Interior, one may think that the Empire had no difficulty in setting out agricultural and agronomic norms but it was not always a matter of course. During the Napoleonic Empire, there were official instructions for everything in agricultural matters. The best agronomists and veterinaries had written, for the Ministry of Interior, instructions about how to grow cotton and colonial plants, how to introduce swedes and curly endives, how to

23. Archives nationales, F10 416.

24. Mémoires d'agriculture et d'économie rurale et domestique publiées par la société d'agriculture du département de la Seine, 1814, t. 17. 
proceed for sheep and horse breeding, etc ${ }^{25}$. On the one hand, the bottom-up dynamics of circulation of knowledge from the departmental societies of agriculture helped the elites of agronomists write these instructions. On the other hand, the debates in the main agronomic Parisian institutions, such as the Museum of Natural History, the veterinary school of Alfort or the Institut National created too many agricultural norms and standards. Sometimes, at this high central level, the scientific arguments were less important than political ones. To be more precise, beneath the official scientific discourse some political issues were raised. The debate about horse-breeding is a good example of this political fact: how should horse breeds be improved by crossing native breeds with foreign ones? By importing foreign purebreds, English ones, in particular? By preserving native breeds? The head veterinary Huzard dithered about what should be done. His first aim was to stop importing horses from England, even if this meant improving the degenerate or degenerating native breeds by crossing them with other foreign ones (Huzard, 1801: 14). The official Anglophobia may explain why there were so many failures in the selective breeding of livestock. The instructions about this never mentioned Robert Bakewell's successful improvements in sheep, cattle and horses and his practice of "in-breeding". Taking advantage of the enclosure movement, of the explosion of the demand for meat in British cities and the food revolution in Britain, Bakewell (1725-95) had empirically managed to master cattle breeding on his Dishley Grange farm in Leicestershire. His goal was to improve breeds so as to produce fast-growing animals. This country gentleman had not renounced the intensive system of breeding but had replaced cross-breeding, which was the fashion of the day, by inbreeding the best specimens of his own animals he had selected (Wykes, 2004; Vissac, 1999; Russel, 1986; Pawson, 1957).

The uncertainties of natural science -a new discipline in progress- can explain other disappointing results (Rey, 1994). Probably the most important debate was the following: were natural conditions so important when introducing new species? The successful introduction of Merinos, Arabian horses and Italian buffalos in France proves that natural conditions were not so important. But the failure of cotton and other colonial plants created confusion. Choosing between sowing exotic plants and practising transplants was a question which remained without any definitive answer. André Thouin, the director of the botanical garden of the Museum, recommended sowing, but the results were not particularly good (Letouzey, 1989: 519-606). In spite of Linné's works, classifying the species was another problem for French scientists. At the Jardin des Plantes of the Museum of Natural History, botanists did not use Linné's nomenclature but those of Tournefort and Jussieu. Some scientific facts were not established yet. Thus some consequences of the ge-

25. Two examples among many others: Gilbert (1798), CHABert and HuZARd (1807). 
netic barriers between species were still unknown and led to resounding failures. In October 1796, when the Papal States had been conquered by the army of the Republic, the French commissaires, among whom Thouin, the botanist and naturalist, had sent Italian buffalos so that they could be used to regenerate French bovids ${ }^{26}$. It was hoped that by cross-breeding Italian buffalos and indigenous cows, they would obtain a better-formed and, more important, a stronger animal which could be used for transport and draught. If the acclimatization of buffalos in the experimental farm of Rambouillet proved successful -calves being even born there- it was absolutely impossible to regenerate French cattle with buffaloes and this failure was bound to happen: the two animals do not belong to the same species ${ }^{27}$ !

The still-birth of an agricultural policy for all can be regarded as another reason for the disappointing results. The agronomists who had set out the agricultural policy of the Consulate and the Empire had clearly said it: they were not aiming at encouraging all the farmers of France but only those who were enlightened, in other words, the class of educated landowners who had enough wealth and land to be able to carry out the prescribed experiments (Silvestre, 1800: 17-18). When he toured his rural department, the Doubs, Prefect Debry did not fail from lambasting the effects of that policy which could not be followed by the vast majority of farmers because they were too poor. The lessons of the Bureau of Agriculture and the imperial network of agricultural societies are useless, he wrote ${ }^{28}$.

Finally, the imperial experiment was too short to change deeply European agriculture. The agricultural policy of self-sufficiency stopped when the Empire fell in 1815. The end of the continental blockade opened the custom barriers to low-cost colonial products. Consequently, there was no longer any need for cotton, tobacco and indigo cultures in Europe. The culture of the sugar beet and the new sugar factories faced a crisis with the resumption of the imports of cane sugar. Average cane sugar production costs were now significantly lower than those for beet sugar.

\section{CONCLUSION: A BIO POLITICAL AND PUBLIC LABORATORY}

The great Napoleonic agricultural policy witnessed some significant success beyond the growth of potato and sugar beet growing. Some species were successfully acclimatized like

26. Archives nationales, AF III 88, D 379.

27. Annales de l'agriculture françoise, 1814, t. 58, pp. 193-251.

28. Archives nationales, F 10 252, "Rapport du préfet du Doubs", Fructidor an IX. 
Merino sheep, Swiss and Dutch cows, Arabic horses, swedes (from Scandinavia), curly endives and chicory. The main achievements were in the introduction of European species and races unknown by most French people and in the attempt at hybridizing foreign and indigenous species in the networks of national experimental institutions (stud farms, sheep farms and national nurseries). By contrast, the acclimatization of tropical seeds or substitutes was a real failure. The main reasons for these failures are the dysfunctions of the bureaucracy, the uncertainties of natural science and agronomy -these new disciplines in progress.

However, the agricultural achievements enlightened the great efficiency of the imperial agricultural system. At each level of the State, at the top within the Ministry of Interior in Paris, as well as at the local state, this system relied on structures wherein scientists, administrators and big landowners worked together on agricultural matters. The imperial agricultural policy put foremost the project of "Agricultural Enlightenment", born in the European continental states after the Seven Years' War (1756-1762) (Jones, 2016). Putting together scientists and administrators under the authority of the Napoleonic State turned this agricultural enlightenment into a real bio political system (Foucault, 2004). The State, at the turn of the $18^{\text {th }}$ and $19^{\text {th }}$ centuries, while claiming to be liberal, was now willing to govern animals and plants and not only human beings.

The financial difficulties of the Empire compromised this policy after 1809 and its fall in 1815 put an end to it. Political time was shorter than agricultural change.

But, this agricultural policy had also a beneficial impact on bio-diversity in Europe, which caused redistribution of species throughout the Napoleonic Empire, even if France benefited from it more than other countries.

Finally, a great biological change occurred gradually after 1815 thanks to these agricultural experiments led during the French Empire. The birth of the thoroughbred Anglo-Arabian horse in France in the 1840s, the birth of a new race of cows (Grandcoing, 2003), the success of the sugar beet after the abolition of slavery (1838 in England; 1848 in France) and the extension of potato growing in the first half of the $19^{\text {th }}$ century, are some of the numerous examples of their long-term impact.

\section{ACKNOWLEDGEMENTS}

This paper was initially presented at the Plenary Session "Global circulation of species and biological innovation, 16th-20th centuries: landscapes, production and consumption", 
coordinated by J. Pujol-Andreu, J. M. Pacheco and A. Polónia at the VI Encontro Rural RePort/XV Congreso de Historia Agraria de la SEHA, "Old and New Worlds: the Global Challenges of Rural History" (Lisbon, 28-30 January 2016). The author would like to aknowledge all the reviewers of Historia Agraria for their attentive review and their invaluable advice.

\section{REFERENCES}

BERDAH, D. (2012). Entre scientifisation et travail de frontières: Les transformations des savoirs vétérinaires en France, XVIII-XIX' siècles. Revue d'histoire moderne et contemporaine, (4), 51-96.

Blomac, N. DE (1991). La gloire et le jeu: Des hommes et des chevaux, 1766-1866. Paris: Fayard.

BlomaC, N. DE (2006). L'Empire et la revalorisation justifiée du cheval limousin. In B. BArrière \& N. DE Blomac (Eds.), Cheval limousin, chevaux en Limousin. Limoges: Presses Universitaires de Limoges.

Bosc, L. A. (1807). Exposition faite à la Societé d'Agriculture du Département de la Seine, du Plan de travail adopté par M. Bosc, Membre de l'Institut de France et Inspecteur des Pépinières, pour étudier et classer les diverses variétés de Vignes cultivées dans les Pépinières du Luxembourg. Annales de l'agriculture françoise, t. 32, 100-25.

Bourde, A. J. (1967). Agronomie et agronomes en France au XVII' siècle. Paris: SEVPEN. Bourguet, M. H. (1997). La collecte du monde: Voyages et histoire naturelle (fin XVII ${ }^{\mathrm{e}-}$ début XIX ${ }^{e}$ siècle). In C. BLANCKAERT et al. (Eds.), Le muséum au premier siècle de son histoire (pp. 163-96). Paris: Museum national d'histoire naturelle.

BRASSART, L. (2014a). "La ferme des animaux" ou l'invention d'une politique de l'animal utile sous le Consulat. Annales historiques de la Révolution française, (377), 17596. http://ahrf.revues.org/13297

BRASSART, L. (2014b). Une politique agricole pour l'Europe? In F. ANTOINE et al. (Eds.), L'Empire napoléonien: Une expérience européenne? (pp. 191-210). Paris: Armand Colin. Bruun-Neergard, T. C. (1808). Mémoires sur la culture de M. le baron de Voght de Flobeck et sur celle de la chicorée dans les environs de Brunswick. Paris: Impr. de Madame Huzard.

Calvel, E. (1805). Traité complet sur les pépinières avec des instructions. Paris: Impr. Marchant.

CHABERT, PH. \& HuZARD, J. B. (1807). Instruction sur la manière de conduire et gouverner les Vaches laitières, imprimée par ordre du Gouvernement. Paris: Impr. de Madame Huzard. 
Doron, C.O. (2016). L’homme altéré: Races et dégénérescence (XVII-XIX siècles). Seyssel: Champ Vallon.

Foucault, M. (2004). Naissance de la biopolitique: Cours au Collège de France. 19781979. Paris: Gallimard/Seuil.

GILBERT, F. H. (1798). Instruction sur les moyens les plus propres à assurer la propagation des bêtes à laine de race d'Espagne et la conservation de cette race dans toute sa pureté, publiée par ordre du gouvernement. Paris: Impr. de la République.

GRANDCOING, P. (2003). Comment naît une race? La race bovine limousine dans la première moitié du XIX ${ }^{\mathrm{e}}$ siècle. Histoire E Sociétés Rurales, (20), 121-46. www.cairn. info/revue-histoire-et-societes-rurales-2003-2-page-121.htm

Guillaume, M. J. (Ed.) (1891). Procès-verbaux du Comité d'instruction publique de la Convention nationale. T. II. Paris: Impr. nationale.

HuZARD, J. B. (1801). Instruction sur l'amélioration des chevaux en France, destinée principalement aux cultivateurs. Paris: Impr. de Madame Huzard.

Jones, P. M. (2016). Agricultural Enlightenment: Knowledge, Technology and Nature, 17501840. Oxford: Oxford University Press.

LACOUR, P. (2014). La République naturaliste: Collections d'histoire naturelle et Révolution française (1789-1804) (pp. 41-135). Paris: Muséum national d'histoire naturelle.

LASTEYRIE, P. DE (1808). Du Cotonnier et de sa culture, de la possibilité et des moyennes d'acclimater cet arbuste en France. Paris: Arthus Bertrand.

Letouzey,Y. (1989). Le fardin des plantes à la croisée des chemins avec André Thouin. Paris: Museum national d'histoire naturelle.

Margairaz, D. (2005). François de Neufchâteau: Biographie intellectuelle (pp. 440-45). Paris: Publications de la Sorbonne.

Mellah, M. (2013). Portrait du berger en figure républicaine ou comment faire entrer l'animal domestique en Révolution. Annales historiques de la Révolution française, (4), 85-110. http://ahrf.revues.org/12966

MeLLAH, M. (2015). L'école d'Alfort, les bêtes à laine et le perfectionnement des arts économiques: De la fin du Directoire à l'Empire. Histoire Eீ Sociétés rurales, (43), 73-102. Moriceau, J. M. (2005). Histoire et géographie de l'élevage français. Paris: Fayard.

Moullier, I. (2004). Le ministère de l'Intérieur sous le Consulat et le Premier Empire (1799-1814): Gouverner la France après le 18 brumaire (pp. 109-110, 337-39). $\mathrm{PhD}$ thesis. Lille: Université de Lille 3.

Mulliez, J. (1983). Les chevaux du Royaume: Histoire de l'élevage du cheval et de la création des haras. Paris: Montalba.

Pawson, C. H. (1957). Robert Bakewell, Pioneer Livestock Breeder. London: Lokwod.

REY, R. (1994). Naissance de la biologie et redistribution des savoirs. Revue de synthèse, 115 (1-2), 167-97. 
Roche, D. (2008a). Les chevaux de la République: L'enquête de l'an III. Revue d'histoire moderne et contemporaine, 55 (4), 82-121.

Roche, D. (2008b). La culture équestre de l'Occident, XVI'-XVII' siècle: L'ombre du cheval. Paris: Fayard.

Russel, N. (1986). Like Engend'ring Like: Heredity and Animal Breeding in Early Modern England. Cambridge: Cambridge University Press.

SILVESTRE, A. F. (1800). Essai sur les moyens de perfectionner les arts économiques en France. Paris: Impr. de Madame Huzard.

SPARY, E. C. (2000). Utopia's garden: French Natural History from Old Regime to Revolution. Chicago: University of Chicago Press.

SPARY, E. C. (2012). Eating the Enlightenment: French Food and the Sciences, 1670-1760. Chicago: University of Chicago Press;

Spary, E. C. (2014). Feeding France: New Sciences of Food, 1760-1815. Cambridge: Cambridge University Press.

Tessier, H. A. (1801). Mémoire sur la nature du sol de l'Isle de Malte, sur ses principales productions, et sur leurs cultures. Annales de l'agriculture française, t. 5, 289-329.

TESSIER, H. A. (1808). Instruction sur la culture du coton en France, deuxième édition augmentée et résultats des premières tentatives faites en 1807 publiées par ordre de S. Ex. le ministre de l'intérieur. Paris: Impr. de Madame Huzard.

Tessier, H. A. (1810). Instruction sur les bêtes à laine et particulièrement sur la race des mérinos contenant la Manière de former de bons Troupeaux, de les multiplier et soigner convenablement en santé et en maladie. Paris: Impr. impériale.

Tessier, H.A. (1839). Histoire de l'introduction et de la propagation des Mérinos en France. Paris: Impr. de Bouchard-Huzard.

Thouin, A. (1803). Description de l'école des plantes d'usage dans l'économie rurale et domestique, établie au Jardin national des plantes de Paris. Annales du Muséum, (2), 142-227.

VIsSAC, B. (1999). Robert Bakewell, pionnier de l'élevage moderne? Ethnozootechnie, (63), 3-14.

WyKES, D. L. (2004). Robert Bakewell (1725-1795) of Dishley: Farmer and Livestock Improver. Agricultural History Review, (1), 38-55. 